\title{
30 \\ COUNTERING EXTREMIST ORGANIZATIONS IN THE INFORMATION DOMAIN
}

Joseph Mroszczyk and Max Abrahms

Over the past 20 years, the frontlines in the fight against extremism have extended across the globe, leaving few corners untouched. This global effort has involved intelligence, law enforcement, and military operations to target extremist networks and prevent future attacks. Simultaneously, there has been a parallel battle in the information domain to shape opinions and change behaviors.

Terrorist and other violent extremist groups, commonly referred to as violent extremist organizations (VEOs), have leveraged 21st-century media and digital communication innovations to disseminate their propaganda instantly around the globe, allowing groups with limited military capabilities to achieve international notoriety and attention.

According to the U.S. Department of Defense, the information environment is "comprised of and aggregates numerous social, cultural, cognitive, technical, and physical attributes that act upon and impact knowledge, understanding, beliefs, world views, and, ultimately, actions of an individual, group, system, community, or organization." "This domain is characterized not by weapons of war but of communication designed to reach international audiences. Haroon Ullah describes this phenomenon as the "weaponization of information" where "the various ways in which information is disseminated are themselves part of the war."2

VEOs have long understood the importance of the information domain in their strategies. Brian Jenkins wrote in 1974 that "terrorism is theater." It is choreographed violence "aimed at the people watching, not at the actual victims." ${ }^{3}$ Indeed, a characteristic that distinguishes terrorism from other forms of violence is that it intends not only to harm the victims but also to signal to other groups and audiences the costs of noncompliance. ${ }^{4}$ As Martha Crenshaw notes, terrorism seeks to "create a psychological effect in a watching audience." ${ }^{5}$ Brigitte Nacos argues that focusing the attention of the public, the media, and government officials "is the raison d'être behind modern terrorism's increasingly shocking violence." ${ }^{\prime}$

This chapter argues that VEOs have advantages in information domain operations due to the inherently dispersed and distributed nature of the environment, complicating efforts to effectively combat the threat. First, it summarizes the major ways VEOs aim to instill fear in a targeted population, particularly by threatening violence and communicating through violence. Second, it discusses the various ways that groups generate appeal by cultivating a moderate image, which can help with recruitment efforts and public support. Third, it provides an overview of the various efforts to counter extremists in the information domain by targeting both messages and key nodes. This chapter is not an exhaustive discussion of the topic but rather explores some of the salient issues. 


\section{Putting the terror in terrorism}

VEOs strive to achieve their strategic goals partly by instilling fear into a targeted population. This objective is a key characteristic of extremist violence that distinguishes it from other types of criminal violence and plays out primarily in the information domain. Bruce Hoffman defines terrorism as "the deliberate creation and exploitation of fear through violence or the threat of violence in the pursuit of political change." " Peter Neumann argues "for an act of terrorism to be effective, it needs to actually terrorize people." ${ }^{8}$ VEOs aim to instill fear primarily through two mechanisms in the information domain: threatening violence and communicating violence.

\section{Threatening violence}

VEOs issue threats of violence even when they do not end up carrying it out. These threats, even if they do not come to fruition, can still achieve effects when it comes to a group's objective to frighten a targeted population and change their behavior. Since terrorists primarily seek to coerce a targeted population and government into accepting their demands, they can derive certain benefits from threatening the costs of noncompliance. ${ }^{9}$ These threats come at relatively low costs to the group and can be released through various media to reach the intended audience.

Joseph Brown finds that terrorists can use threats "to manipulate perceptions, induce fear, and obtain concessions," which can serve as a substitute for violence. When combined with acts of violence, threats can gain more legitimacy and allow a group to increase the longevity of their campaigns. Brown concludes that VEOs should "take full advantage of threats" because they are effective at intimidating civilians, shaping the impact of violence, and achieving limited concessions. ${ }^{10}$

Numerous VEOs stoke fear with threats even when they are not backed up by force. For example, the Islamic State has long promised that it will attack Rome and Vatican City, even depicting St. Peter's Square on the cover of Dabiq, its propaganda magazine. In August 2017, the commander of the Swiss Guards, the Vatican's security force, said it was only "a matter of time" before the group carried out an actual attack. Security measures at the Vatican have been increased in recent years in response to these threats. Although the Islamic State has not successfully attacked the Vatican to date, the threat alone has managed to modify the behavior of the Swiss Guards. ${ }^{11}$

Al-Shabaab has also regularly issued threats against the United States and its allies outside of Africa. In February 2015, for example, the al-Qaida affiliate threatened to attack malls in the United States, including the Mall of America, as well as malls in Canada and the United Kingdom. These threats were given additional credibility because of the group's attack on the Westgate Mall in Kenya that killed 67 people in 2013. Although the U.S. Department of Homeland Security said there was no "specific evidence" of this threat, it still warned Americans to be "particularly careful" if they visited the Mall of America. ${ }^{12}$

Lashkar-e-Taiba also routinely issues threats against targets in India, prompting heightened security measures and media coverage. VEOs understand that they can gain attention, stoke fear and other reactions in the target country through the information domain, even in the absence of physical attacks.

\section{Communicating violence}

Of course, VEOs are even more likely to elicit a response in the target country by carrying out physical attacks. As a form of communication, there is no substitute for violence, according to many militant leaders, who admit that they escalated to violence because their grievances had been ignored.

As the leader of the Tamil Tigers put it: "The Tamil people have been expressing their grievances ... for more than three decades. Their voices went unheard like cries in the wilderness." "13 The head of the United Red Army, an obscure offshoot of the Japanese Red Army, likewise admitted: "There is no other 
way for us. Violent actions . . . are shocking. We want to shock people everywhere. . . It is our way of communicating with the people." ${ }^{14}$ Usama bin Ladin and Ayman al-Zawahiri described 9/11 as a "message with no words," which is "the only language understood by the West." 15

For this reason, political scientists often describe terrorism as a political communication strategy. ${ }^{16}$ By using violence, terrorists reveal to the target that they possess the power to cause harm and are highly motivated to change the political status quo. ${ }^{17}$ VEOs select tactics and targets to maximize fear. ${ }^{18}$ Assaf Moghadam contends that VEOs use suicide tactics to elicit greater anxiety in the target. ${ }^{19}$ Diego Gambetta agrees that suicide tactics confer a "communicative benefit" compared to other types of attacks. ${ }^{20}$ Vehicular attacks are also a materially inexpensive method recommended by the leadership of al-Qaida and the Islamic State to maximize impact and gain publicity. ${ }^{21}$

Hostage-taking is another tactic that guarantees publicity. It has been described as "smart" terrorism because it can achieve a number of effects in the information domain, especially prolonged media coverage and the forced recognition of the group in negotiations. ${ }^{22}$ The communicative effect of hostage-taking was starkly displayed in 2016 when Islamic State terrorists seized an upscale bakery in Dhaka, Bangladesh, resulting in an 11-hour standoff with security forces. During the standoff, one attacker asked staff members to turn on the Wi-Fi so he could post images of the attack. ${ }^{23}$

The right-wing terrorist Brenton Tarrant also used modern technologies to livestream his March 2019 attack in real time on two mosques in Christchurch, New Zealand, which left 51 people dead. Prior to the attack, Tarrant announced on an extremist website that he would conduct an attack and would livestream it on Facebook. As Graham Macklin points out, Tarrant's video "was not so much a medium for his message insomuch as it was the message." Although less than 200 people watched the attack live, it received approximately 4,000 views before Facebook took the video down 12 minutes after the broadcast ended. ${ }^{24}$

Other terrorist attacks have also been livestreamed, such as an October 2019 attack at a synagogue in Germany in which the gunman killed two people and streamed a 35-minute video on Twitch, which gained 2,200 views before it was removed. ${ }^{25}$ Livestreaming attacks allows extremists to display their violence in an unfiltered manner to maximize its communicative impact.

Al-Qaida was among the first VEO to understand cyberspace as a critical component of the information domain. ${ }^{26}$ The group matured under the leadership of Bin Ladin, who prioritized perception. He was obsessed with messaging, image, and rapid dissemination of information, ${ }^{27}$ believing that "a huge part of the battle is in the media." ${ }^{28}$ His successor, Ayman al-Zawahiri, likewise noted that "more than half of this battle is taking place in the battlefield of the media." ${ }^{29}$

Al-Qaida in Iraq (AQI) was particularly notorious for its use of violence as a communication strategy. Following the U.S. invasion of Iraq in 2003, AQI, under the leadership of Abu Musab al-Zarqawi, embraced the art of publicizing violence. AQI's videos were "designed to shock, mortify, and instill absolute fear in its enemies" by showcasing beheadings and other forms of executions. ${ }^{30}$

In May 2014, AQI released a video displaying al-Zarqawi beheading American Nicholas Berg. The video received widespread international attention, and parts of the video were shown on major news outlets in the United States. ${ }^{31}$ In the following days, the most popular internet searches were related to the video. $^{32}$ This display of violence was staged to maximize its coverage while also demonstrating the willingness of the group to carry out horrific acts of violence in pursuit of its objectives.

More than any other VEO, the Islamic State distinguished itself by publicizing violence with modern technology. Charlie Winter's analysis of Islamic State propaganda videos confirms that brutality emerged as a primary theme. ${ }^{33}$ Judith Tinnes finds that the Islamic State conducted 2,281 camera-recorded killings from January 2015 through November 2020, with most involving shootings (60.13\%) and beheadings $(28.76 \%)$ but also other forms of brutal executions. ${ }^{34}$ The goal of these recorded killings is to maximize media attention and fear. ${ }^{35}$

Most analysts believe that the Islamic State's gory propaganda has a "strategic logic" and is indeed effective. ${ }^{36}$ According to Abdel Bari Atwan, the Islamic State "could never have achieved its territorial 
ambitions, nor could it have recruited such a large army in so short a time, without its mastery of the internet." ${ }^{37}$ Michael Weiss and Hassan Hassan add that the Islamic State's secret sauce has been its "slick propaganda machine," especially its "peerless ability to produce sleek, hour-long propaganda and recruitment films." 38

Charles Lister also attributes Islamic State success to its "slick propaganda media releases," as these "jihadists in particular proved especially adept at managing their use of social media and the production of qualitatively superior video and imagery output." ${ }^{39}$ The international media has promoted this interpretation, with the New York Times stating,

Where the Islamic State innovated the most was in carrying out increasingly gruesome violence explicitly to film it - to intimidate enemies and to draw recruits with eye-catching displays on social media. . . Those techniques have proved so effective. ${ }^{40}$

Wired magazine went so far as to say that "Islamic State has been singularly successful" because of its unique ability to "inspire dread" and "cultivate this kind of image." 41 And yet, these assessments were made before the Islamic State group lost its caliphate and imploded.

\section{Benefits of a moderate face}

Terrorists must prioritize not only fear but also sympathy. ${ }^{42}$ For this reason, VEOs can benefit from restraint, particularly against civilians. ${ }^{43}$ A growing body of scholarship finds that extremism often backfires. By attacking civilians, VEOs risk strengthening the resolve of the target country, ${ }^{44}$ lowering the odds of government concessions, ${ }^{45}$ eroding popular support, ${ }^{46}$ and expediting organizational demise. ${ }^{47}$ For this reason, militant leaders often try to present their organizations as more moderate than the actual behavior of their members, especially when they kill civilians.

Militant leaders cultivate a more moderate image by denying organizational involvement or denying principal intent. ${ }^{48}$ In denial of organizational involvement, the leader refrains from claiming organizational credit when members attack civilians. In denial of principal intent, the leader acknowledges that his members attacked civilians but denies the violence reflects his intentions.

\section{Denial of organizational involvement}

The Taliban leadership eagerly assumes organizational responsibility for selective attacks against military targets. For instance, the Taliban quickly claimed responsibility when operatives ambushed Mohammad Qasim Fahim, the leader of the alliance that toppled the Taliban in 2001, on a road in northern Kunduz in July 2009. ${ }^{49}$ By contrast, Taliban leaders veil organizational involvement when operatives commit indiscriminate bloodshed.

The United Nations Assistance Mission in Afghanistan observes that Taliban attack denials are "frequently issued following civilian casualty incidents . . . perhaps highlighting the Taliban's continuous interest in gaining the Afghan people's support." ${ }^{50}$ For example, Taliban leadership released the following statement when operatives defied its orders by striking the International Committee of the Red Cross in Jalalabad: "The Islamic Emirate of Afghanistan wants to clarify to everyone that it was neither behind the May 29th attack on the [Red Cross] office in Jalalabad city nor does it support such attacks." ${ }^{1}$

According to Information Minister Mian Iftikhar Hussain of Pakistan's Khyber-Pakhtunkhwa Province, Taliban leaders eschew credit for civilian violence because "they are desperate to wash their tainted image among the public." ${ }^{52}$ In sum, anecdotal evidence abounds of the Taliban leadership denying organizational involvement when members attack civilians to enhance the image of the group. 
Quantitative research confirms that leaders are significantly likely to deny organizational responsibility when their members strike civilian targets versus military ones. Research finds that leaders are 41\% less likely to claim credit for attacks on civilian targets than military ones. ${ }^{53}$ Evidently, leaders become more careful about appearing too extreme with greater exposure to asymmetric conflict.

Groups are significantly less likely to claim credit over time, and the results strengthen for those groups that have survived at least a decade. The percentage of civilian attacks in particular for which groups claim credit also decreases over time, especially after a decade of fighting. ${ }^{54}$ The wisdom of moderate branding through denial of organizational involvement is at least partly a learned behavior. Over time, leaders gain knowledge about how to advance the cause even when their members subvert it.

Similarly, another study of VEOs finds that they tend to feature in their propaganda videos significantly fewer attacks against civilian targets than their members actually commit. By contrast, attacks on military targets are overrepresented. ${ }^{55}$ In these ways, militant leaders manage the marketing of their organization's violence to obscure its harm toward civilians and thereby gain sympathy, especially with locals.

\section{Denial of principal intent}

Denying organizational involvement is not always a realistic public relations strategy because sometimes leaders cannot credibly deny organizational responsibility when civilians are attacked. To distance the organization from the counterproductive attack, leaders often deny principal intent to demonstrate that the atrocity does not represent the values of the group, especially those at the top. Denial of principal intent is achieved through several image restoration techniques familiar to students of the communications literature.

Perhaps the most common face-saving technique is an apology. Militant leaders issue apologies surprisingly frequently. According to one study, leaders have apologized for $22 \%$ of attacks. Target selection is the key factor. Civilian casualties reportedly increase the odds four-fold of an apology on behalf of the group. ${ }^{56}$ The Irish Republican Army (IRA) leadership, for example, initially denied organizational responsibility for a December 1983 car bombing outside the Harrods department store in central London that killed two civilians and injured 14 bystanders.

But when denial of organizational involvement became implausible, the leaders pursued the denial of principal intent public relations strategy by issuing an apology. ${ }^{57}$ The IRA also apologized in 1987 when a bomb killed 11 bystanders at a memorial service for veterans in Northern Ireland. The public statement read: "The IRA admits responsibility for planting the bomb in Enniskillen yesterday which exploded with such catastrophic consequences. We deeply regret what occurred." ${ }^{58}$

In 2006, Hezbollah leader Hassan Nasrallah apologized for a rocket attack that killed two Israeli Arab children in Nazareth in northern Israel. "To the family that was hit in Nazareth, on my behalf and my brothers', I apologize to this family," Nasrallah said, apparently recognizing the political costs the attack had incurred. ${ }^{59}$

Over the years, al-Qaida leaders have increasingly issued apologies when members harmed civilians. In 2009, the American al-Qaida spokesman Adam Gadahn released a video message in English to "express our condolences to the families of the Muslim men, women, and children killed" in terrorist attacks in Afghanistan and Pakistan. ${ }^{60}$ In 2013, al-Qaida in the Arabian Peninsula struck a hospital that left dozens of people dead. Its leader Qasim al-Raymi released an apology through its media outlet. ${ }^{61}$

Following the massive truck bomb attack in Mogadishu in December 2019 that killed more than 80 people, al-Shabaab claimed credit for the blast but apologized that Somalis were killed, which the group said was meant to target a convoy of Turkish mercenaries. ${ }^{62}$ When civilians are struck, such apologies help militant leaders to project more positive intentions both personally and on behalf of their organization.

Militant leaders typically combine apologies with scapegoating to distance themselves from the offense. Essentially, the principal blames the unwanted attack on its agents. In their apology for the 
1983 Harrods attack, the IRA Army Council claimed it had "not authorized the attack" and blamed undisciplined operatives. ${ }^{63}$ Similarly, the IRA said that the Enniskillen attack was "not sanctioned by the leadership." ${ }^{64}$

The leader of Lashkar-e-Taiba, Hafiz Muhammad Saeed, blamed the 2008 Mumbai attacks and other instances of violence against the population on "rogue elements within the group." 65 Apologizing and scapegoating are often combined with corrective action, where the leader attempts to demonstrate the genuineness of his opposition to the unwanted violence against civilians by punishing the perpetrators for it. The IRA apology for the Enniskillen attack made a point to mention that the perpetrators would be subject to an "internal inquiry." ${ }^{66}$ Such public punishments are a form of crisis communications to help militant leaders distance themselves and their other members from the terrorism fallout.

\section{Converting support to action}

In sum, VEOs are not single-mindedly focused on fear maximization. Most leaders are sensitive to their organization's public image. Especially when civilians are harmed, they are known to practice both denial of organizational involvement and denial of principal intent. It explains why most VEOs around the world are significantly less likely to claim organizational responsibility for civilian attacks, and when organizational culpability is undeniable, the leaders maintain their image by apologizing, blaming it on wayward operatives and punishing them to signal to audiences that the terrorist carnage does not represent the values of the group. In these ways, VEOs are able to attract supporters and sympathizers.

VEOs must not only use the information environment to attract supporters, but they must convert these supporters into members to replenish its ranks. A group's longevity depends upon its ability to connect with candidates and convince them to join the group. ${ }^{67}$ In addition to strategically managing the effects of their violence through denial of organizational involvement and denial of principal intent, VEOs use the information domain to promote the quality of life their members enjoy ${ }^{68}$ distribute violent propaganda to appeal to certain individuals who find violence alluring, ${ }^{69}$ and position their group as more resolute than competing organizations. ${ }^{70}$

VEOs can reach a wider pool of candidates through the use of digital communications. As Sageman points out, prior to 2004, most Islamist terrorist networks developed as a result of face-to-face interactions among friends and family. After 2004, these interactions shifted to the internet as organizations adapted to the new information environment. ${ }^{71}$

Social media has emerged as a critical node of recruitment in the information domain, which has come to be known as this decade's version of the "radical mosque" in terms of its importance as a meeting space for the dissemination of radical ideologies. Though the social media ecosystem has become the meeting place for groups to connect with potential members, it is not the reason for radicalization and recruitment into VEOs. Rather, it functions as a meeting place for these processes to occur, just as mosques or bookshops once did. ${ }^{72}$ According to Weimann, social media offers VEOs a number of advantages in terms of their ability to recruit online, giving them free, reliable, and accessible platforms to reach their targeted audiences and disseminate material worldwide. ${ }^{73}$

\section{Government responses}

VEOs must be contested in the information domain, the critical battlespace in the war against extremism. Counterterrorism cannot be limited to killing extremists, capturing them, disbanding their networks, or hardening potential targets. For sustained success, governments must promote narratives to reduce the appeal of extremist messages and to delegitimize their voices across the information spectrum.

The U.S. government acknowledged this need early in the war on terrorism following $9 / 11$, and the effort has evolved into a larger international counterextremism enterprise composed of new bureaucracies, private 
sector cooperation, and expanded authorities. Two key aspects of winning the information domain are effective counternarrative messaging and cutting off the nodes through which messages are disseminated.

\section{Messages}

The United States lacked the bureaucratic infrastructure to organize an information war against extremism on 9/11, and it has continued to lag behind VEOs. Following the attacks, the George W. Bush administration acknowledged the need to enhance the image of the United States within the Muslim world. In October 2001, advertising executive Charlotte Beers was brought in to serve as undersecretary of state for public diplomacy. She led the Shared Values Initiative, an effort to promote the United States to Muslims abroad and to demonstrate that American values are not antithetical to Islam. The effort floundered due to resistance from diplomats within the Department of State who viewed the outreach as a transparent propaganda campaign. The Shared Values Initiative was canceled shortly after it began, with supporters contending that the effort was never given a chance to take root. ${ }^{74}$

The 2006 National Security Strategy highlighted the importance of winning the information war to counter terrorism. It noted that the war on terrorism was both a "battle of arms and a battle of ideas-a fight against the terrorists and against their murderous ideology." The document highlighted the ongoing war in Iraq had been "twisted by terrorist propaganda as a rallying cry" and that extremism was emanating from "sub-cultures of conspiracy and misinformation" and from an "ideology that justifies murder." Counterterrorism success, the document remarked, "means winning the battle of ideas, for it is ideas that can turn the disenchanted into murderers willing to kill innocent victims." 75

The Barack Obama administration attempted to enhance American "soft power" and public diplomacy in the information domain. Secretary of State Hillary Clinton subsequently developed in 2011 what became known as the Center for Strategic Counterterrorism Communications. Its task was to "coordinate, orient, and inform government-wide foreign communications activities targeted against terrorism and violent extremism."

The center grew to about 40 personnel within the first year, about half of whom were on the Digital Outreach Team charged with engaging in online debates about violent extremism. ${ }^{76}$ The center pursued a number of strategies to counter VEO messages, including reaching out to young people and extremists themselves on social media websites. Most of its efforts focused on countering messaging from the Islamic State, although the center also targeted VEOs in Somalia and Nigeria. ${ }^{77}$

The Obama administration replaced the Center for Strategic Counterterrorism Communications with the Global Engagement Center in 2016. The Global Engagement Center was charged with leading "the coordination, integration, and synchronization of Government-wide communications activities directed at foreign audiences abroad in order to counter the messaging and diminish the influence of international terrorist organizations." To these ends, the center sought to use the latest technologies, data analytics, and a whole-of-government approach to counter extremist narratives in the information domain. The center's stated goal is to expose the "true nature" of VEOs in order to reduce their appeal and diminish their influence among potential sympathizers and prospective recruits. ${ }^{78}$

The core mission of the center evolved under the Donald Trump administration with the National Defense Authorization Act of 2017, which codified the Global Engagement Center into law. Initially focused on countering messaging from VEOs, its mission expanded to include both "foreign state and non-state propaganda and disinformation efforts." ${ }^{79}$ This reflected a broadening of security threats to include adversarial states, particularly China and Russia.

Ingram highlights two additional changes that took place during the transition of the Center for Strategic Counterterrorism Communications to the Global Engagement Center. First, the new center prioritized coordination and capacity building across U.S. government agencies, non-government sectors, and international allies by enhancing data analytics capabilities. Second, the center moved away from its own 
messaging efforts and instead focused on strengthening the ability of these partners to engage in their own strategic communications. The center had transformed "from soloist to conductor," as one senior Department of State official put it. ${ }^{80}$

Despite these changes, the 2017 National Security Strategy acknowledged that U.S. efforts to counter its enemies in the information domain had been "tepid and fragmented." These initiatives "lacked a sustained focus" and suffered from a lack of properly trained professionals. The strategy called for the strengthening of "Information Statecraft" to counter the weaponization of information by U.S. enemies, including both state and non-state actors. Priority actions in the strategy included the need to improve understanding of "how adversaries gain informational and psychological advantages" and "craft and direct coherent communications campaigns to advance American influence and counter challenges from the ideological threats," such as those emanating from VEOs. ${ }^{81}$

The subsequent National Defense Strategy of 2018 similarly emphasized the role of the information domain and called for the need to "gain and maintain information superiority" in times of both peace and war. ${ }^{82}$ The 2018 National Strategy for Counterterrorism acknowledged that the United States had developed a robust counterterrorism architecture since the 9/11 attacks but had still "not developed a prevention architecture to thwart terrorist radicalization and recruitment." Toward those ends, the strategy listed a number of priority actions related to the information domain, including the need to combat extremist ideologies with strategic communications. ${ }^{83}$

In sum, nearly two decades after the $9 / 11$ attacks and the advent of the war on terrorism, the United States continues to play catch-up in the information domain. While tremendous strides have been made to disrupt terror networks, kill or capture leaders, and remove safe havens, there have not been parallel successes in the information environment. Many efforts are admittedly clandestine in nature, but it is nonetheless evident that the United States remains in a reactive posture in the information domain, struggling to link tactics and strategies to combat the influence of extremism online.

\section{Key nodes}

In addition to targeting VEO messaging, governments and private-sector partners can choke the spread of these messages through critical nodes - such as social media platforms - by limiting access and removing content. Technology companies have historically not been liable for the user content posted on their websites. Section 230 of the 1996 Communications Decency Act states that "no provider or user of an interactive computer service shall be treated as the publisher or speaker of any information provided by another information content provider," effectively protecting social media platforms, as well as companies that provide internet services, from liability for the content posted on their sites. Under Section 230, social media companies can choose to remove posts or content that are in violation of their own standards so long as they act in "good faith." 84

In recent years, however, there has been a renewed debate about whether "Big Tech" should bear some responsibility for the content posted on their platforms. The Department of Justice concluded in its June 2020 analysis of Section 230 that "reform is important now more than ever" with the growth of criminal activity on the internet. ${ }^{85} \mathrm{~A}$ reform proposed by the Department of Justice is to hold platforms accountable for a few types of particularly illicit content, such as child exploitation and abuse, cyberstalking, and terrorism. This reform would incentivize platforms to address these issues to stave off lawsuits from victims. ${ }^{86}$

Social media companies acknowledge that their platforms have been exploited by VEOs to spread extremist content and are taking steps to minimize this problem. In 2017, YouTube, Facebook, Microsoft, and Twitter founded the Global Internet Forum to Counter Terrorism to "prevent terrorists and violent extremists from exploiting digital platforms." It has since expanded to include more than a dozen other 
technology companies that work collaboratively to combat the dissemination of violent extremist content online.

Critics of this forum allege that-through the group's efforts to block or limit the dissemination of extremist content using algorithms - it has also removed other legitimate content that should be protected under free speech. More broadly, critics fear that government participation on a new Global Internet Forum to Counter Terrorism Independent Advisory Committee could increase the risk of what they see as extra-legal censorship. ${ }^{87}$

Facebook regularly shares metrics related to its efforts to remove extremist content from its platform. According to the company, it bans "groups that proclaim a hateful and violent mission from having a presence on our apps and we remove content that represents, praises, or supports them." Accordingly, it has developed automated techniques to detect content from groups like the Islamic State and al-Qaida.

In the first three months of 2020, Facebook removed 4.7 million pieces of content, an increase of over 3 million pieces compared to the previous three months. The company reported that it had increased its "proactive detection rate" - the content removed before it is reported-from $89.6 \%$ in the last quarter of 2019 to $96.7 \%$ in early $2020 .{ }^{88}$ The company recognizes the need not only to identify and remove extremist content but to also empower counter-narratives. ${ }^{89}$

While websites may have the ability to remove content, traditional media outlets, such as newspapers, still offer an outlet through which VEOs can publicize their message. There have been efforts to develop an ethical code of practice for media coverage of terrorism to limit its negative impact, such as fear, and enhance positive effects, like messages of resilience. ${ }^{90}$

The United Nations has also published a handbook for journalists covering terrorism "to explore some of the ethical dilemmas present in terrorism coverage, and start a conversation with media professionals as to how to respond appropriately and proportionately." ${ }^{11}$ At least in societies with a free press, measures such as these would need to emanate from the media itself, since governments generally lack legal authority to impose restrictions on how journalists report.

\section{Conclusion}

In sum, VEOs have demonstrated far greater adaptability, maneuverability, and innovation in the information domain in the past 20 years than the governments and organizations tasked with countering them. Extremist tactics and techniques are constantly evolving in parallel with the rapid transformation of the digital communication space, often leaving governments behind to develop bureaucracies and authorities to counter this threat. As Ingram concludes, strategic communications efforts against the Islamic State "have been dogged by bureaucratic disjointedness and instability," creating "a strategic-policy vacuum" that has hampered consistent messaging against the group. ${ }^{92}$

Governments have an inherent structural disadvantage when combating extremism in the information domain due to the sheer velocity at which innovation is taking place. Alberto Fernandez, former director of the Center for Strategic Counterterrorism Communications at the U.S. Department of State, notes that governments "with their sometimes elephantine decision-making processes, public oversight and multiple stakeholders, are often at a disadvantage compared to nimble, streamlined terrorist or insurgent forces in the field of propaganda." 93

Extremists have not only demonstrated innovation and creativity with the manner in which they conduct violence but have matured their information domain operations to deliver catered messages toward targeted audiences and for different effects, such as to instill fear or to generate support often by disassociating themselves from unpopular attacks. It is difficult to assess how effective extremist messaging has been due to a variety of methodological challenges, but more needs to be done to limit the capability of VEOs to exploit the information domain. 


\section{Notes}

1 Joint Chiefs of Staff, Joint Concept for Operating in the Information Environment (JCOIE) (Washington, DC: Joint Chiefs of Staff, 2018), 42.

2 Haroon K. Ullah, Digital World War: Islamists, Extremists, and the Fight for Cyber Supremacy (New Haven: Yale University Press, 2017), 3.

3 Brian M. Jenkins, International Terrorism: A New Kind of Warfare (Santa Monica: RAND, 1974), 4.

4 Boaz Ganor, The Counter-Terrorism Puzzle: A Guide for Decision Makers (New Brunswick, NJ: Transaction Publishers, 2005), 234-236; Brigitte L. Nacos, Mass-Mediated Terrorism: The Central Role of the Media in Terrorism and Counterterrorism (Lanham, MD: Rowman \& Littlefield, 2007), 14.

5 Martha Crenshaw, Explaining Terrorism: Causes, Processes and Consequences (New York: Routledge, 2011), 3.

6 Brigitte L. Nacos, Terrorism \& the Media: From the Iran Hostage Crisis to the Oklahoma City Bombing (New York: Columbia University Press, 1994), 8.

7 Bruce Hoffman, Inside Terrorism (New York: Columbia University Press, 2006), 40.

8 Michele McPhee and Brian Ross, "Official: American May Be Key in ISIS Social Media Blitz," ABC News, September 3, 2014, https://abcnews.go.com/blogs/headlines/2014/09/official-american-may-be-key-in-isis-socialmedia-blitz/.

9 Andrew H. Kydd and Barbara F. Walter, “The Strategies of Terrorism," International Security 31, no. 1 (2006): 49-80.

10 Joseph M. Brown, Force of Words: The Logic of Terrorist Threats (New York: Columbia University Press, 2020), 166-173.

11 Jack Moore, “Pope's Swiss Guards Say ‘Only Matter of Time’Before ISIS Attacks Rome, Vatican,” Newsweek, August 25, 2017, www.newsweek.com/popes-swiss-guards-say-only-matter-time-isis-attacks-rome-vatican-655025.

12 Faith Karimi et al., "Al-Shabaab Threatens Malls, Including Some in U.S.; FBI Downplays Threat," CNN, February 21, 2015, www.cnn.com/2015/02/21/us/al-shabaab-calls-for-mall-attacks/index.html.

13 Louise Richardson, What Terrorists Want: Understanding the Enemy, Containing the Threat (New York: Random House, 2007), 50.

14 Gerald McKnight, The Mind of the Terrorist (London: Michael Joseph, 1974), 168.

15 Peter Bergen, "Interview with Osama bin Laden," CNN, 1997.

16 Robert A. Pape, Dying to Win: The Strategic Logic of Suicide Terrorism (New York: Random House, 2005). See also Max Abrahms, "Al Qaeda's Miscommunication War: The Terrorism Paradox," Terrorism and Political Violence 17, no. 4 (2005): 529-549.

17 Max Abrahms, "The Credibility Paradox: Violence as a Double-Edged Sword in International Politics," International Studies 57, no. 4 (2013): 660-671.

18 Nicholas J. O'Shaughnessy and Paul R. Baines, "Selling Terror: The Symbolization and Positioning of Jihad," Marketing Theory 9, no. 2 (2009): 227-228.

19 Assaf Moghadam, The Globalization of Martyrdom: Al Qaeda, Salafi Jihad, and the Diffusion of Suicide Attacks (Baltimore: Johns Hopkins University Press, 2008), 31.

20 Diego Gambetta, "Can We Make Sense of Suicide Missions," in Making Sense of Suicide Missions, ed. Diego Gambetta (New York: Oxford University Press, 2005), 266.

21 Brian M. Jenkins and Bruce R. Butterworth, "Smashing Into Crowds"-An Analysis of Vehicle Ramming Attacks (San Jose: Mineta Transportation Institute, 2019), 10.

22 Margaret G. Hermann and Charles E. Hermann, "Hostage Taking, the Presidency, and Stress," in Origins of Terrorism: Psychologies, Ideologies, Theologies, States of Mind, ed. Walter Reich (Washington, DC: Woodrow Wilson Center Press, 1998), 211-229.

23 Julfikar Ali Manik and Kai Schultz, "Bangladesh Sentences 7 to Death Over 2016 Bakery Attack," New York Times, November 27, 2019, www.nytimes.com/2019/11/27/world/asia/bangladesh-bakery-attack.html.

24 Graham Macklin, "The Christchurch Attacks: Livestream Terror in the Viral Video Age," CTC Sentinel 12, no. 6 (2019): 18-29.

25 Max Koslowski, "Social Media Companies Thwarted Spread of Latest Terror Livestream," Sydney Morning Herald, October 10, 2019, www.smh.com.au/politics/federal/social-media-companies-thwarted-spread-of-latest-terrorlivestream-20191010-p52zhk.html.

26 Malcom Nance and Chris Sampson, Hacking ISIS: How to Destroy the Cyber Jihad (New York: Skyhorse Publishing, 2017), 25-29.

27 Jim Michaels, "Bin Laden Was Obsessed with Media, Public Image," USA Today, March 1, 2016, www.usatoday. com/story/news/world/2016/03/01/bin-laden-obsessed-media-public-image/81164054/.

28 Peter Bergen, “Bin Laden’s Final Days—Big Plans, Deep Fears," CNN, March 19, 2012, www.cnn.com/2012/03/16/ opinion/bergen-bin-laden-final-writings/index.html. 


\section{The information domain}

29 Quoted in Akil N. Awan, "The Virtual Jihad: An Increasingly Legitimate Form of Warfare," CTC Sentinel 3, no. 5 (2010): 10.

30 Nance and Sampson, Hacking ISIS, 27.

31 Maria Newman, "Video Appears to Show Beheading of American Civilian," New York Times, May 11, 2004, www. nytimes.com/2004/05/11/international/middleeast/video-appears-to-show-beheading-of-american.html.

32 “Berg Video Dominates Net Searches," Sydney Morning Herald, May 20, 2004, www.smh.com.au/national/bergvideo-dominates-net-searches-20040520-gdiyj3.html.

33 Charlie Winter, The Virtual 'Caliphate': Understanding Islamic State's Propaganda Strategy (London: Quilliam, 2015), $22-23$.

34 Judith Tinnes, "Counting Lives Lost-Monitoring Camera-Recorded Extrajudicial Executions by the 'Islamic State'," Perspectives on Terrorism 10, no. 1 (2016): 78-82.

35 Ibrahim Al-Marashi, "The Truth About Beheadings," Al Jazeera, November 24, 2014, www.aljazeera.com/ opinions/2014/11/24/the-truth-about-beheadings/.

36 Steven T. Zech and Zane M. Kelly, "Off With Their Heads: The Islamic State and Civilian Beheadings," Journal of Terrorism Research 6, no. 2 (2015): 85.

37 Abdel Bari Atwan, Islamic State: The Digital Caliphate (Berkeley: University of California Press, 2015), 15.

38 Michael Weiss and Hassan Hassan, ISIS: Inside the Army of Terror (New York: Simon \& Schuster, 2016), XV and 171.

39 Charles R. Lister, The Syrian Jihad: Al-Qaeda, the Islamic State and the Evolution of an Insurgency (New York: Oxford University Press, 2016), 240, 244.

40 Anne Barnard and Neil MacFarquhar, "Paris and Mali Attacks Expose Lethal Qaeda-ISIS Rivalry," New York Times, November 20, 2015, www.nytimes.com/2015/11/21/world/middleeast/paris-and-mali-attacks-expose-a-lethalal-qaeda-isis-rivalry.html.

41 Brendan Koerner, "Why ISIS Is Winning the Social Media War-And How to Fight Back," Wired, March 2016, www.wired.com/2016/03/isis-winning-social-media-war-heres-beat/.

42 Martha Crenshaw, "The Causes of Terrorism,” Comparative Politics 13, no. 4 (1981): 387.

43 Max Abrahms, "Why Terrorism Does Not Work," International Security 31, no. 2 (2006): 42-78.

44 Claude Berrebi and Esteban F. Klor, "Are Voters Sensitive to Terrorism? Direct Evidence From the Israeli Electorate," American Political Science Review 102, no. 3 (2008): 279-301; Max Abrahms, "Does Terrorism Really Work? Evolution in the Conventional Wisdom Since 9/11," Defence and Peace Economics 22, no. 6 (2011): 583-594; Christophe Chowanietz, "Rallying Around the Flag or Railing Against the Government? Political Parties' Reactions to Terrorist Acts," Party Politics 17, no. 5 (2010): 673-698.

45 Anna Getmansky and Tolga Sinmazdemir, "Success Breeds Failure: The Effect of Terrorist Attacks on Land Control in the Israeli-Palestinian Conflict" (paper presented at the annual meeting of the American Political Science Association, New Orleans, LA, September 2012); Max Abrahms, "The Political Effectiveness of Terrorism Revisited," Comparative Political Studies 45, no. 3 (2012): 66-93; Max Abrahms and Matthew S. Gottfried, "Does Terrorism Pay? An Empirical Analysis," Terrorism and Political Violence 28, no. 1 (2016): 72-89; Khusrav Gaibulloev and Todd Sandler, "The Impact of Terrorism and Conflicts on Growth in Asia," Economics and Politics 21, no. 3 (2009): 359-383.

46 Martha Crenshaw, "The Logic of Terrorism: Terrorist Behavior as a Product of Strategic Choice," in Terrorism in Perspective, ed. Sue Mahan and Pamala L. Griset (London: Sage Publications, 2007), 24-34; Walter Reich, "Understanding Terrorist Behavior: The Limits and Opportunities of Psychological Inquiry," in Origins of Terrorism: Psychologies, Ideologies, Theologies, States of Mind, ed. Walter Reich (Washington, DC: Woodrow Wilson Center Press, 1998), 261-279.

47 Audrey Kurth Cronin, How Terrorism Ends: Understanding the Decline and Demise of Terrorist Campaigns (Princeton: Princeton University Press, 2009); Nelly Lahoud et al., Letters from Abbottabad: Bin Ladin Sidelined? (West Point: Combating Terrorism Center, 2012).

48 Max Abrahms, Rules for Rebels: The Science of Victory in Militant History (New York: Oxford University Press, 2018).

49 Whadat Afghan, "Afghan Vice-Presidential Candidate Survives Ambush," Reuters, July 26, 2009, www.reuters.com/ article/us-afghanistan-attack/afghan-vice-presidential-candidate-survives-ambush-idUSTRE56P0R 220090726.

50 United Nations Assistance Mission in Afghanistan, Afghanistan Annual Report 2013: Protection of Civilians in Armed Conflict (Kabul: United Nations, 2014), 32.

51 Azam Ahmed and Matthew Rosenberg, "Taliban Deny Responsibility for Attack on Red Cross," New York Times, May 31, 2013, www.nytimes.com/2013/06/01/world/asia/taliban-deny-responsibility-for-attack-onred-cross.html.

52 "Ashfaq Yusufzai, "Pakistan: Taliban Backs Off From Attacking Civilians," Inter Press Service, July 23, 2011, www. ipsnews.net/2011/07/pakistan-taliban-backs-off-from-attacking-civilians/. 
53 Max Abrahms and Justin Conrad, "The Strategic Logic of Credit Claiming: A New Theory for Anonymous Terrorist Attacks," Security Studies 26, no. 2 (2017): 279-304.

54 Max Abrahms et al., "Explaining Civilian Attacks: Terrorist Networks, Principal-Agent Problems and Target Selection," Perspectives on Terrorism 12, no. 1 (2018): 23-45.

55 Max Abrahms et al., "What Terrorist Leaders Want: A Content Analysis of Terrorist Propaganda Videos," Studies in Conflict \& Terrorism 40, no. 17 (2017): 899-916.

56 Ioana Emy Matesan and Ronit Berger, "Blunders and Blame: How Armed Non-State Actors React to Their Mistakes," Studies in Conflict \& Terrorism 40, no. 5 (2017): 376-398.

57 "IRA Says Harrods Bombing Was a Mistake," United Press International, December 30, 1983, www.upi.com/ Archives/1983/12/30/IRA-says-Harrods-bombing-was-a-mistake/2270441608400/?ur3=1.

58 Matesan and Berger, "Blunders and Blame," 388.

59 "Hezbollah Leader Apologizes for Attack's Child Victims," CNN, July 21, 2006, www.cnn.com/2006/WORLD/ meast/07/20/nasrallah.interview/.

60 "Al Qaeda Offers 'Condolences' for Innocent Victims," CNN, December 13, 2009, www.cnn.com/2009/ WORLD/asiapcf/12/12/afghanistan.alqaeda/index.html.

61 Yousuf Basil and Catherine E. Shoichet, "Al Qaeda: We're Sorry About Yemen Hospital Attack," CNN, December 22, 2013, www.cnn.com/2013/12/22/world/meast/yemen-al-qaeda-apology/index.html.

62 Graeme Baker, "Al-Shabaab Says Sorry for Killing Somalis With Huge Lorry Bomb," The Times, December 31, 2019, www.thetimes.co.uk/article/al-shabaab-says-sorry-for-killing-somalis-with-huge-lorry-bomb-kp6lcctpb.

63 Alan O’Day, Political Violence in Northern Ireland: Conflict and Conflict Resolution (Westport, CT: Praeger, 1997), 20.

64 Matesan and Berger, "Blunders and Blame," 388.

65 V.S. Subrahmanian et al., Computational Analysis of Terrorist Groups: Lashkar-e-Taiba (New York: Springer, 2013), 34.

66 Matesan and Berger, "Blunders and Blame," 388.

67 Hoffman, Inside Terrorism, 225.

68 Winter, The Virtual 'Caliphate,' 28-31.

69 Brian M. Jenkins, "The Allure of ISIS for Young Recruits," The RAND (Blog), March 20, 2015, www.rand.org/ blog/2015/03/the-allure-of-isis-for-young-recruits.html.

70 Kydd and Walter, "The Strategies of Terrorism," 51.

71 Marc Sageman, Leaderless Jihad: Terror Networks in the Twenty-First Century (Philadelphia: University of Pennsylvania Press, 2008), 109-123.

72 Winter, The Virtual 'Caliphate,' 7.

73 Gabriel Weimann, “Terrorist Migration to Social Media," Georgetown Journal of International Affairs 16, no. 1 (2015): 182. For more on the research challenges surrounding extremist recruitment activities via social media, see Maura Conway, "Determining the Role of the Internet in Violent Extremism and Terrorism: Six Suggestions for Progressing Research," Studies in Conflict \& Terrorism 40, no. 1 (2017): 77-98.

74 Margaret Seymour, "The Problem With Soft Power," Foreign Policy Research Institute, September 14, 2020, www. fpri.org/article/2020/09/the-problem-with-soft-power/.

75 White House, National Security Strategy (Washington, DC: White House, 2006), 9-10.

76 Richard Stengel, Information Wars: How We Lost the Global Battle Against Disinformation \& What We Can Do About It (New York: Grove Press, 2019), 60-61.

77 Brian Knowlton, "Digital War Takes Shape on Websites Over ISIS," New York Times, September 26, 2014, www. nytimes.com/2014/09/27/world/middleeast/us-vividly-rebuts-isis-propaganda-on-arab-social-media.html.

78 "Global Engagement Center," U.S. Department of State, accessed December 8, 2020, https://2009-2017.state.gov/r/ gec/index.htm.

79 “Global Engagement Center: Core Mission \& Mission,” U.S. Department of State, accessed December 8, 2020, www. state.gov/bureaus-offices/under-secretary-for-public-diplomacy-and-public-affairs/global-engagement-center/.

80 Haroro J. Ingram, Persuade or Perish: Addressing Gaps in the U.S. Posture to Confront Propaganda and Disinformation Threats (Washington, DC: The George Washington University Program on Extremism, 2020), 9.

81 White House, National Security Strategy (Washington, DC: White House, 2017), 34-35.

82 Department of Defense, Summary of the 2018 National Defense Strategy of the United States of America (Washington, DC: U.S. Department of Defense, 2018), 6.

83 White House, National Strategy for Counterterrorism (Washington, DC: White House, 2018), 21-22.

84 Barbara Ortutay, "AP Explains: The Rule That Made the Modern Internet," Associated Press, October 28, 2020, https://apnews.com/article/what-is-section-230-tech-giants-77bce70089964c1e6fc87228ccdb0618.

85 Department of Justice, Section 230-Nurturing Innovation or Fostering Unaccountability? Key Takeaways and Recommendations (Washington, DC: U.S. Department of Justice, 2020), 1.

86 Ibid., 3. 
87 “JointLetterto NewExecutive Director, GlobalInternetFormto CounterTerrorism,'HumanRights Watch,July30, 2020, www.hrw.org/news/2020/07/30/joint-letter-new-executive-director-global-internet-forum-counter-terrorism.

88 “An Update on Combating Hate and Dangerous Organization,” Facebook, May 12, 2020, https://about.fb.com/ news/2020/05/combating-hate-and-dangerous-organizations/.

89 Erin Saltman, "Countering Terrorism and Violent Extremism at Facebook: Technology, Expertise and Partnerships," Observer Research Foundation, August 27, 2020. www.orfonline.org/expert-speak/countering-terrorismand-violent-extremism-at-facebook/\#_edn1.

90 Jessica White, Terrorism and the Mass Media (London: Royal United Services Institute, 2020).

91 Moez Chakchouck, "Foreword" to Jean-Paul Marthoz, Terrorism and the Media: A Handbook for Journalists (New York: United Nations, 2017).

92 Haroro J. Ingram, A Brief History of Propaganda During Conflict: Lessons for Counter-Terrorism Strategic Communications (The Hague: International Centre for Counter-Terrorism, 2016), 32.

93 Alberto M. Fernandez, "Measuring the Unmeasurable: Evaluating the Effectiveness of US Strategic Counterterrorism Communications," in The Sage Handbook of Propaganda, ed. Paul Baines et al. (London: Sage, 2020). 